\title{
Amazon environmental services: Why Brazil's Highway BR-319 is so damaging
}

\author{
Philip M. Fearnside
}

Amazonia is recognized for its global importance in climate regulation and for its extraordinary biological and cultural diversity, including distinctions such as the UNESCO World Heritage site status of the Central Amazon Conservation Area. Unfortunately, the Brazilian government's current and planned actions promote widespread deforestation and degradation that threaten the environmental services that the Amazon forest supplies to Brazil and to the world. The last large block of intact forest in the Brazilian Amazon is now threatened by planned roads. These would unleash processes that, despite political discourse, are outside of the control of the Brazilian government (Fearnside 2020a).

Highway BR-319 (Fig. 1) would connect the notorious "arc of deforestation" in southern Amazonia to Manaus in central Amazonia (Fearnside and Graça 2006). This road was built in the early 1970s and was abandoned in 1988; since 2015, a "maintenance" program has made it marginally passable during the dry season, and the road is now planned for "reconstruction." Deforestation actors and processes can be expected to migrate to all areas connected to Manaus by road, such as Roraima in northern Amazonia (Barni et al. 2015), and to the vast area of forest in the western part of the state of Amazonas that would be opened by roads planned to connect to BR-319 (Fearnside et al. 2020a). Brazil is totally unprepared for containing the destruction that this change in the geography of deforestation represents (Fearnside 2018).

This situation has been worsened by Brazil's environmental agencies and legislation having been largely gutted during the presidential administration of Jair Bolsonaro that began in January 2019 (Ferrante and Fearnside 2019). Politicians in Manaus claim that BR-319 would be a "model of sustainability for the world," but all indications suggest otherwise. The highway route is basically a lawless area today (Andrade et al. 2021; Ferrante et al. 2021), and the government hardly has the funds for the road construction itself, let alone for a massive governance program that would be needed to protect dozens of affected indigenous lands and conservation units (protected areas for biodiversity). Reconstruction of BR-319 must wait for a future epoch in terms of capacity and political will in the environmental area. Fortunately, this wait would not represent a sacrifice.

The highway project is not economically viable (Teixeira 2007; Fleck 2009). It is the only large infrastructure project in Brazil that lacks an economic viability study (EVTEA), most likely for the obvious reason that such a study would reveal its unviability. As compared to transport via BR-319, transporting the products from factories in the Manaus Free Trade Zone to São Paulo is cheaper using the current system of barges carrying truck trailers to Belém, and it would be much cheaper still if an adequate port were built in Itacoatiara to carry containers to Southeast Brazil in oceangoing ships. Politicians in Manaus are the most visible beneficiaries of BR-319, since championing the highway project is a key strategy for winning votes in the city.

Manaus has a population of 2.2 million, or $1 \%$ of the population of Brazil. Because BR-319 is to be rebuilt by the federal government (that is, by taxpayers throughout Brazil), almost the entire cost is to be paid by the $99 \%$ who do not live in Manaus. One argument presented by Manaus politicians to justify this is that Amazonia has been exploited by the rest of Brazil for centuries, and so there a debt to be paid to the region. This argument may resonate in Manaus, but it is unlikely to be convincing in São Paulo. It would be especially unconvincing if the population of São Paulo was to realize that up to $70 \%$ of their water 


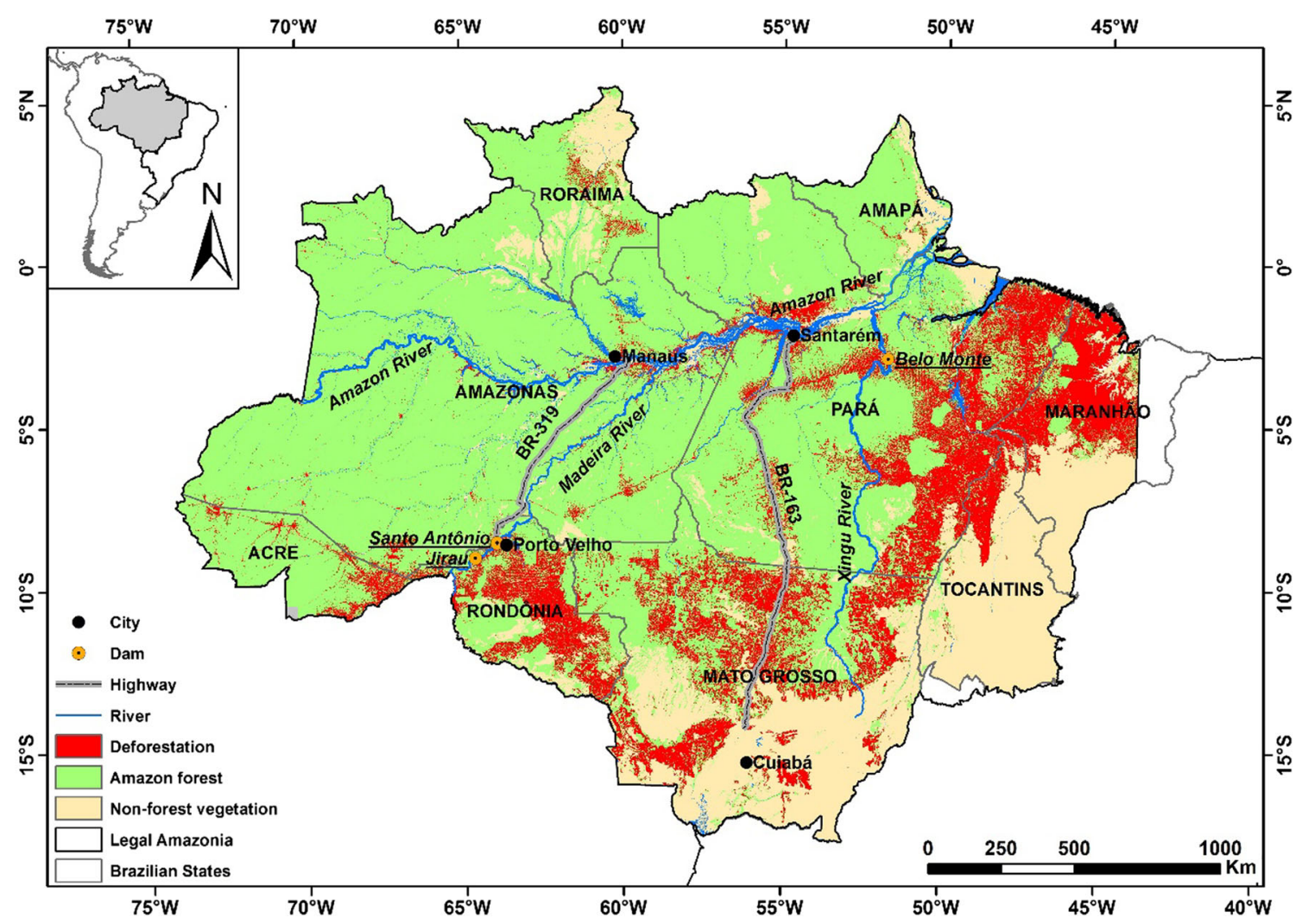

Fig. 1 Deforestation in Brazil's Legal Amazon Region by 2018 (Data from Brazil, INPE 2021). Deforestation has so far been concentrated in the "arc of deforestation" along the southern and eastern edges of the forest. Highway BR-319 (Manaus-Porto Velho) and associated side roads would give deforesters access to the vast area of forest in the western part of the state of Amazonas

depends on keeping the Amazon forest standing (van der Ent et al. 2010; Zemp et al. 2014).

Of particular concern is a planned state highway (AM366) that would branch off BR-319 to the west and pass through the first drilling blocks of the massive planned "Solimões Sedimentary Basin" project for oil and gas extraction in an area bigger than the US state of California (Fearnside 2020b) (Fig. 2). The blocks that would be traversed by AM-366 have already been bought by the Russian oil giant Rosneft (Brazil, DNIT 2020, p. 106), and such a powerful company would likely influence government authorities to speed the construction of AM-366. Spontaneous illegal side roads are also likely to appear, as is already happening along BR-319 (Fearnside et al. 2020b). One of them even follows the planned route of AM-366, cutting through an indigenous land and a national park (Fearnside et al. 2020a).

The vast area that would be opened to the west of BR319 holds high biodiversity and a rich diversity of indigenous peoples (Ferrante et al. 2020). It is also the source of water vapor that is recycled by the trees and transported to São Paulo by winds known as "flying rivers" (Arraut et al. 2012; Keys et al. 2012). This area holds an enormous stock of carbon that, if released over a short period of years, would be critical in pushing the global climate system past a tipping point where a "runaway greenhouse" would accelerate outside of human control (Nogueira et al. 2015; Barros and Fearnside 2019).

Potential global impacts of allowing the western, central, and northern Amazon to be opened for destruction are of sufficient magnitude that those in other parts of the world must consider both their roles in the destructive processes in progress in Brazil and the potential influence that they have on events in the country. Brazil is the world's largest exporter of both beef and soy, which are the two commodities with the greatest impact on Amazon deforestation (e.g., Fearnside et al. 2013). Brazil's politicians are very sensitive to attending to the interests of the country's agribusiness sector, and any threat of restrictions by importing countries and companies has a strong influence on decisions (Ferrante and Fearnside 2022). All countries, companies, and individuals must consider the indirect impacts that their purchasing has elsewhere in the world, including impacts that come back to affect them directly through climate change.

In short, Highway BR-319 will be a social, economic, and ecological disaster. This highway and its planned side roads threaten a part of the Amazon that needs to be 


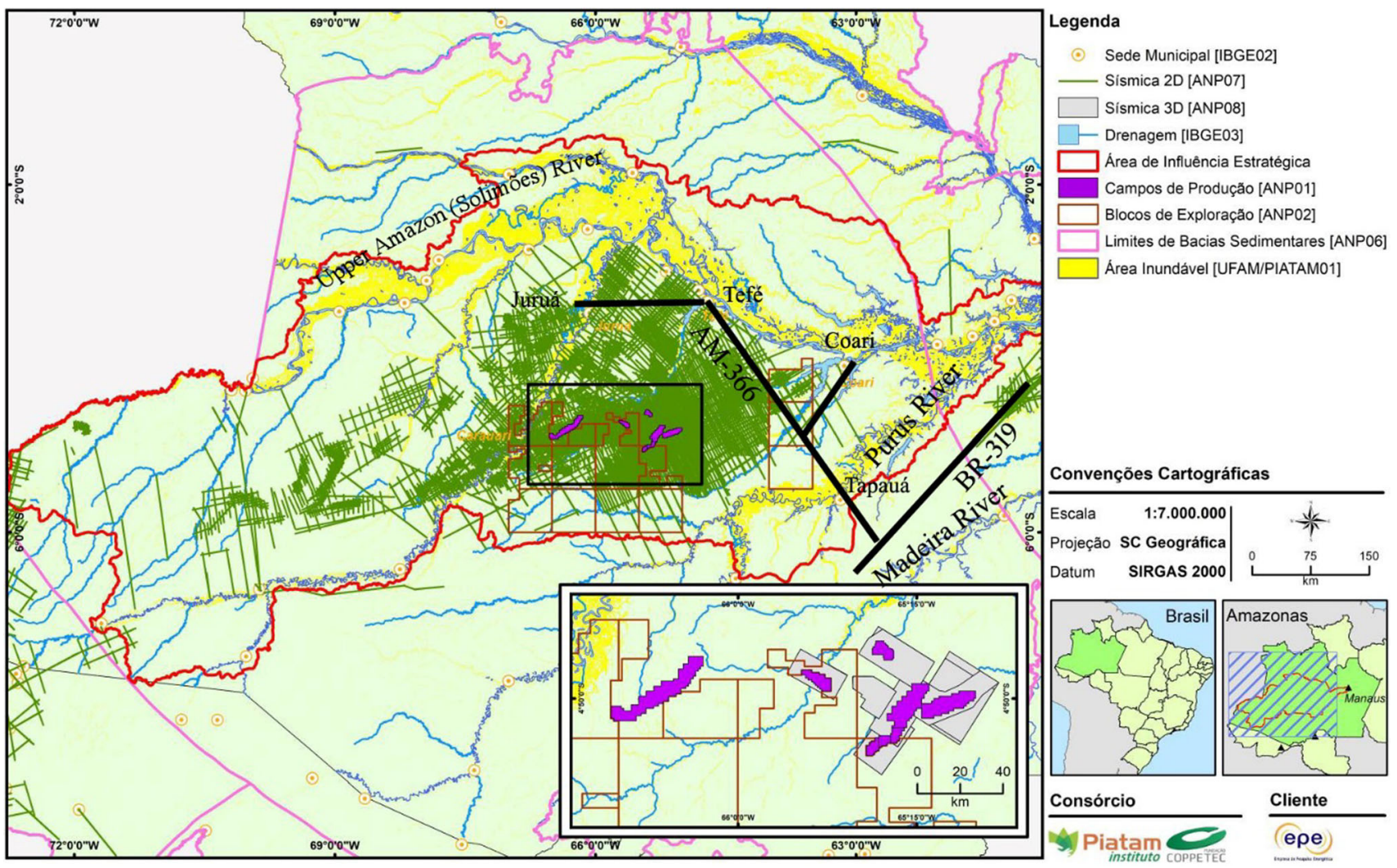

Fig. 2 Map of the planned "Solimões Sedimentary Basin" oil and gas project. The purple areas have wells currently in production. The thin green lines represent locations already surveyed by seismic methods for future drilling. The project's $740000-\mathrm{km}^{2}$ "strategic area of influence" is outlined in red; it is larger than the US state of California. Source for oil and gas project: Brazil, EPE (2020, p. 65); Source for planned roads: Brazil, DNIT (2002)

maintained in forest to generate the environmental services that this biologically diverse habitat provides to the local people, the wider Brazilian population, and the rest of the world.

Acknowledgements The author's research is funded by the National Council for Scientific and Technological Development $(\mathrm{CNPq}$ 311103/2015-4), the Foundation for the Support of Research of the State of Amazonas (FAPEAM 01.02.016301.000289/2021) and the Brazilian Research Network on Climate Change (FINEP/Rede Clima 01.13.0353-00). M.A. dos Santos Junior prepared Figure 1.

\section{REFERENCES}

Andrade, M., L. Ferrante, and P.M. Fearnside. 2021. Brazil's Highway BR-319 demonstrates a crucial lack of environmental governance in Amazonia. Environmental Conservation 48: 161-164. https://doi.org/10.1017/S0376892921000084.

Arraut, J.M., C.A. Nobre, H.M. Barbosa, G. Obregon, and J.A. Marengo. 2012. Aerial rivers and lakes: Looking at large-scale moisture transport and its relation to Amazonia and to subtropical rainfall in South America. Journal of Climate 25: 543-556. https://doi.org/10.1175/2011JCLI4189.1.

Barni, P.E., P.M. Fearnside, and P.M.L.A. Graça. 2015. Simulating deforestation and carbon loss in Amazonia: Impacts in Brazil's Roraima state from reconstructing Highway BR-319 (Manaus-
Porto Velho). Environmental Management 55: 259-278. https:// doi.org/10.1007/s00267-014-0408-6.

Barros, H.S., and P.M. Fearnside. 2019. Soil carbon is decreasing under "undisturbed" Amazonian forest. Soil Science Society of America Journal 83: 1779-1785. https://doi.org/10.2136/ sssaj2018.12.0489.

Brazil, DNIT (Departamento Nacional de Infraestrutura de Transportes). 2002. Mapa Rodoviário Amazonas. Brasília: DNIT. https://bit.ly/3EMegng.

Brazil, DNIT (Departamento Nacional de Infraestrutura de Transportes). 2020. Estudo do Componente Indígena CI Preliminar da Etnia 3 Apurinã - Rev C. Brasília: DNIT. https://bit.ly/3mMpWAr.

Brazil, EPE (Empresa de Pesquisa Energética). 2020. Estudo Ambiental de Área Sedimentar na Bacia Terrestre do Solimões. Relatório SOL-EA-60-600.0010-RE-R0. Manaus and Rio de Janeiro: EPE. https://bityl.co/4kWJ.

Brazil, INPE (Instituto Nacional de Pesquisas Espaciais). 2021. Projeto PRODES - monitoramento da floresta amazônica brasileira por satélite. São José dos Campos: INPE. http://www.dpi. inpe.br/prodesdigital/.

Fearnside, P.M. 2018. Challenges for sustainable development in Brazilian Amazonia. Sustainable Development 26: 141-149. https://doi.org/10.1002/sd.1725.

Fearnside, P.M. 2020a. BR-319: The beginning of the end for Brazil's Amazon forest (commentary). Mongabay, 3 November 2020a. https://bityl.co/4skE.

Fearnside, P.M. 2020b. Oil and gas project threatens Brazil's last great block of Amazon forest (commentary). Mongabay, 9 March 2020b. https://bit.ly/3ELLZxt. 
Fearnside, P.M., and P.M.L.A. Graça. 2006. BR-319: Brazil's Manaus-Porto Velho Highway and the potential impact of linking the arc of deforestation to central Amazonia. Environmental Management 38: 705-716. https://doi.org/10.1007/ s00267-005-0295-y.

Fearnside, P.M., A.M.R. Figueiredo, and S.C.M. Bonjour. 2013. Amazonian forest loss and the long reach of China's influence. Environment, Development and Sustainability 15: 325-338. https://doi.org/10.1007/s10668-012-9412-2.

Fearnside, P.M., L. Ferrante, A.M, Yanai, and M.A. Isaac Júnior. 2020a. Trans-Purus: Brazil's last intact Amazon forest at immediate risk (commentary). Mongabay, 24 November 2020. https://bityl.co/4o8J.

Fearnside, P.M., L. Ferrante, and M.B.T. Andrade. 2020b. BR-319 illegal side road threatens Amazon protected area, indigenous land (commentary). Mongabay, 27 March 2020. https://bit.ly/ $3 \mathrm{mPj} 4 \mathrm{SR}$.

Ferrante, L., and P.M. Fearnside. 2019. Brazil's new president and "ruralists" threaten Amazonia's environment, traditional peoples and the global climate. Environmental Conservation 46: 261-263. https://doi.org/10.1017/S0376892919000213.

Ferrante, L., and P.M. Fearnside. 2022. Countries should boycott Brazil over export-driven deforestation. Nature 601: 318. https:// doi.org/10.1038/d41586-022-00094-7.

Ferrante, L., M. Gomes, and P.M. Fearnside. 2020. Amazonian indigenous peoples are threatened by Brazil's Highway BR-319. Land Use Policy 94: art. 104548. https://doi.org/10.1016/j. landusepol.2020.104548.

Ferrante, L., M.B.T. Andrade, M.L. Leite, C.A. Silva Junior, M. Lima, M.G. Coelho Junior, E.C. da Silva Neto, D. Campolina, et al. 2021. Brazil's highway BR-319: The road to the collapse of the Amazon and the violation of indigenous rights. Die Erde 152: 65-70. https://doi.org/10.12854/erde-2020-552.
Fleck, L. 2009. Eficiência Econômica, Riscos e Custos Ambientais da Reconstrução da BR 319. Lagoa Santa: Conservation Strategy Fund. https://bit.ly/3FL59F1.

Keys, P.W., R.J. van der Ent, L.J. Gordon, H. Hoff, R. Nikoli, and H.H.G. Savenije. 2012. Analyzing precipitationsheds to understand the vulnerability of rainfall dependent regions. Biogeosciences 9: 733-746. https://doi.org/10.5194/bg-9-733-2012.

Nogueira, E.M., A.M. Yanai, F.O.R. Fonseca, and P.M. Fearnside. 2015. Carbon stock loss from deforestation through 2013 in Brazilian Amazonia. Global Change Biology 21: 1271-1292. https://doi.org/10.1111/gcb.12798.

Teixeira. K.M. 2007. Investigação de Opções de Transporte de Carga Geral em Conteineres nas Conexões com a Região Amazônica. PhD thesis. São Carlos: Universidade de São Paulo. https://bit.ly/ 3FNeuMv.

van der Ent, R.J., H.H.G. Savenije, B. Schaefli, and S.C. SteeleDunne. 2010. Origin and fate of atmospheric moisture over continents. Water Resources Research 46: art. W09525. https:// doi.org/10.1029/2010WR009127.

Zemp, D.C., C.F. Schleussner, H.M.J. Barbosa, R.J. van der Ent, J.F. Donges, J. Heinke, G. Sampaio, and A. Rammig. 2014. On the importance of cascading moisture recycling in South America. Atmospheric Chemistry and Physics 14: 13337-13359. https:// doi.org/10.5194/acp-14-13337-2014.

Publisher's Note Springer Nature remains neutral with regard to jurisdictional claims in published maps and institutional affiliations.

\section{Philip M. Fearnside ( $\square)$}

Address: National Institute for Research in Amazonia (INPA), Av. André Araújo, 2936, Manaus, Amazonas CEP 69.067-375, Brazil. e-mail: pmfearn@inpa.gov.br 